\title{
Symmetrical Fibrous Hyperplasia of the Palate
}

\section{Simetrična fibrozna hiperplazija nepca}

\author{
University Hospital Clinic Zagreb \\ Zavod za oralnu kirurgiju Stomatološkog fakulteta Sveučilišta u Zagrebu \\ 2 School of Dental Medicine University of Zagreb \\ Stomatološki fakultet Sveučilišta u Zagrebu
}

\begin{abstract}
Bilateral symmetrical fibrous palate hyperplasia is not a common case in the literature. The cause of this pathological change is not completely known. The development of hyperplasia may also be associated with a genetic mutation in the gingival soft tissue or gingival injury. We present a case of a 47-year-old patient who developed a formation that manifested bilaterally in the hard palate. After the excision, there were no histological elements in the material that indicated aggressive behavior of the formation. The clinical and histological diagnosis was the bilateral symmetrical palate hyperplasia, which is a very rare condition.
\end{abstract}

\author{
Received: December 4, 2020 \\ Accepted: April 20, 2021 \\ Address for correspondence \\ Tomislav Katanec, PhD, DMD \\ University Hospital Clinic Zagreb, \\ Department of Oral Surgery \\ Phone: +38598948 2617 \\ tkatanec@sfzg.hr \\ MeSH terms: Palate; Hyperplasia \\ Author keywords: Fibroses, bilateral \\ hyperplasia, hard palate
}

\section{Introduction}

Fibrous hyperplasia or palate fibroma is a rare benign soft tissue tumor of the hard palate that occurs in about $1.2 \%$ of cases in the adult population $(1,2)$. In most cases, it appears as a unilateral, solid formation whose diameter rarely exceeds $1 \mathrm{~cm}$. It is covered with a neat palatine mucosa (3). Predisposing factors for the formation are genetic heredity, infections with viral agents, consumption of Betel nut, immunodeficiency as well as lack of protein in the diet (4). In $3-6 \%$ of cases, the formation may malignantly alter to squamous cell carcinoma. This may be due to an abnormal response of fibrous tissue to chronic inflammatory irritation (5). About $9 \%$ of these formations develop from the area of the interdental papilla. The formations are smaller in diameter, occurring more frequently in the female population, between the ages of twenty and thirty. They are usually found on a wide base and the surface color is pink to red (6). Differential diagnostic lesion can be characterized as epulis, peripheral ameloblastoma, peripheral gigantocellular granuloma, and pyogenic emerging granuloma or cemento-ossifying fibroma. Also, the formation can be characterized as bilateral hard palate fibromatosis (7).

Connective tissue proliferation may be associated with attachment gingival injury, gingival sulcus injury or the occurrence of a foreign body in the sulcus. The development of hyperplasia may also be associated with a genetic mutation in the gingival soft tissue (8).

\section{Uvod}

Fibrozna hiperplazija ili fibrom nepca rijedak je dobroćudni tumor mekog tkiva tvrdoga nepca koji se u odrasloj populaciji pojavljuje u oko $1,2 \%$ slučajeva $(1,2)$. Uglavnom je to unilateralna, čvrsta, solidna tvorba s promjerom rijetko većim od $1 \mathrm{~cm}$. Prekrivena je urednom nepčanom sluznicom (3). Predisponirajući čimbenici za nastanak tvorbe su genetska predispozicija, infekcija virusnim agensima, konzumiranje behtelova oraščića te imunodeficijencija i nedostatak proteina u prehrani (4). U 3 do $6 \%$ slučajeva tvorba može maligno alterirati u planocelularni karcinom. Razlog za to može biti nenormalni odgovor fibroznog tkiva na kroničnu upalnu iritaciju (5). Oko $9 \%$ navedenih tvorbi nastaje u području interdentalne papile. Tvorbe su manjeg promjera i češće su u ženskoj populaciji u dobi između 20 i 30 godina. Obično se nalaze na širokoj bazi, a površina je ružičaste do crvene boje (6). Diferencijalnodijagnostički leziju možemo okarakterizirati kao epulis, periferni ameloblastom, periferni gigantocelularni granulom, ili kao piogeni granulom u nastajanju ili cemento-osificirajući fibrom. Možemo je također okarakterizirati kao bilateralnu fibromatozu tvrdog nepca (7).

Proliferacija vezivnoga tkiva može biti povezana $s$ ozljedom pričvrsne gingive, ozljedom gingivalnog sulkusa ili pojavom stranog tijela u sulkusu. Nastanak POF-a može biti povezan is genetskom mutacijom gingivalnoga mekog tkiva (8). 


\section{Case report}

In our case, a 47-year-old patient developed a formation that manifested bilaterally in the hard palate area and spread all the way to the border with the soft palate. Fibromatous formation appeared 3 years before the examination. Initial$\mathrm{ly}$, it grew as a small nodule that a year before began to develop into a bulky fibromatous formation larger than $5 \mathrm{~cm}$ in diameter on each side. The mass extended from the area of the upper canines on both sides to the border with the soft palate. The formation was palpably hard and connected at a wide base to the palatal artery. It showed no signs of acute inflammation. The surface of the formation was smooth, and it was the same color as the surrounding mucosa. The formation was completely painless. In the health history, the patient did not report any trauma or irritation of the palate in the past three years. She denied any illnesses or allergies, as well as taking any medications.

Patohistological (PHD) analysis of the formation taken from the left side of the palate revealed that it was a fibromatous change per magna, which was removed completely. The size of the change on the left side of the palate measured $2.6 \mathrm{x}$ $1.5 \times 0.9 \mathrm{~cm}$ and on the right side $3.2 \times 2.5 \times 2 \mathrm{~cm}$. The formation was constructed on both the left and the right side of an almost acellular hyaline binder, with no observed mitotic or proliferative activity after immunohistochemical staining for Ki-67. The surface of the formation was covered with a multilayered squamous epithelium. There were no histological elements in the material that indicated aggressive behavior of the formation.

\section{Prikaz slučaja}

U našem slučaju pacijentica u dobi od 47 godina imala je tvorbu koja se pojavila bilateralno u području tvrdog nepca i šrila se sve do granice s mekim nepcem. Fibromatozna tvorba pojavila se prije tri godine. Početno je rasla kao mali čvor koji se unatrag godinu dana počeo razvijati u glomaznu fibromatoznu tvorbu promjera $5 \mathrm{~cm}$ sa svake strane. Masa se protezala od područja gornjih očnjaka obostrano do granice s mekim nepcem. Tvorba je palpatorno bila tvrda, na širokoj bazi povezana s palatinalnom arterijom. Nije pokazivala znakove akutne upale. Površina joj je bila glatka, a boja poput boje okolne sluznice. Bila je potpuno bezbolna. $U$ anamnezi pacijentice nije bila navedena nikakva trauma ili iritacija na nepcu unatrag tri godine. Pacijentica je negirala bilo kakvu bolest ili alergije te uzimanje bilo kakvih lijekova.

PHD analizom uzorka tvorbe uzetog s lijeve strane nepca ustanovljeno je da je riječ o fibromatoznoj promjeni per magna te je uklonjena u cijelosti. Veličina promjene s lijeve strane nepca iznosila je 2,6 x 1,5 x 0,9 cm, a s desne strane 3,2 x $2,5 . \times 2 \mathrm{~cm}$. Tvorba je i s lijeve is desne strane bila građena od gotovo acelularnog hijalinog veziva, bez uočene mitozne ili proliferativne aktivnosti nakon imunohistokemijskog bojenja na Ki 67. Površina tvorbe bila je prekrivena višeslojnim pločastim epitelom. U materijalu nije bilo histoloških elemenata koji upućuju na agresivno ponašanje.
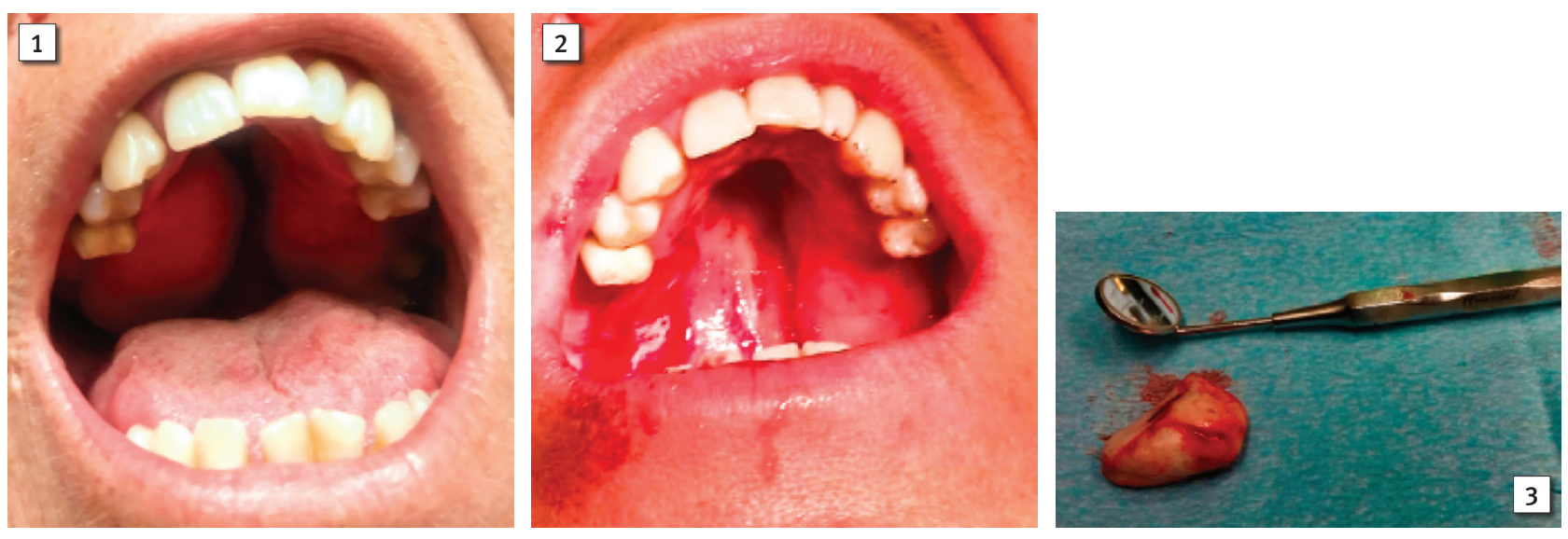

Figure 1 Symmetric fibromatous hyperplasia

Slika 1. Simetrična fibromatozna hiperplazija

Figure 2 Excision of the formation on the right side of the palate

Slika 2. Ekcizija tvorbe s desne strane nepca

Figure 3 The size of the formation after excision

Slika 3. Veličina tvorbe nakon ekscizije

Figure 4 Histological presentation of tissue sample

Slika 4. Histološka slika uzorka 


\section{Discussion}

The development of symmetrical palate hyperplasia is of unknown etiology and may be associated with various predisposing factors. There are various names in the literature for this formation such as fibrous epulis or calcifying fibroblastic granuloma (9). Peripheral fibroids and oral fibromatosis $>1 \mathrm{~cm}$ in diameter were linked by immunohistochemical analysis to CD34, alpha-smooth muscle actin (a-SMA), vimentin, Ki-67 (Mib1) and transforming growth factor-alpha (TGF- $\alpha$ ). TGF- $\alpha$ is thought to be associated with fibroblast proliferation and enhanced fibroblastic activity (10). It is clinically difficult to distinguish between a neoplasm and an uncontrolled reactive hyperplasia of fibrous tissue. Trauma and irritation are still considered to be the main predisposing factors for the occurrence of fibromatous formations in the area of the oral cavity (11). Eversole and Leider in their study stated that the recurrence was present in $28 \%$ of cases, after enucleation of intraosseous ossifying fibroma (12). Such formations are difficult to differentiate diagnostically from peripheral giant cell granulomas, fibromas, pyogenic granulomas, neurofibromatosis, schwannoma, lipoma, calcifying odontogenic cysts and several other odontogenic and nonodontogenic cysts (13).

In the literature review from 1950 to 2017, different names for formations of similar shapes and appearances are encountered. Hiebert and Brooks used the name hard palate fibroma in 1950 and histopathological analysis of their sample found that the formation contained accumulations of fibroblasts and mature connective tissue cells (14). For a similar formation, Beers used the term bilateral palate fibroma with almost identical finding of patohistological (PHD) analysis (15). In the period from 2010 to 2017, Di Lorenzo et al.and Palaia called such changes the symmetrical fibrous hyperplasia of the palate and idiopathic symmetrical hyperplasia of the palate $(16,17)$.

In 2017 Syed et al. called the change in the palate symmetrical palatal fibromatosis. A histological analysis of the formation describes avascular fibrous tissue with a thin collagen network and a very weak mitotic activity, with minimal accumulation of inflammatory infiltrate (18). Vasconcelos et al. in their paper described the formation in a 47-year-old patient as collagen fibroma. It develops bilaterally on the tubercle of the maxilla and spreads to the soft palate. The formation grows slowly and contains fibroblasts and myofibroblasts. The histological pattern was described identically as the PHD finding in our patient (19). Mesquita et al. described the case of a 37-year-old patient with a unilateral nodular fibromatous formation on the left side of the palate, extending throughout the left part of the hard and soft palate. A patohistological and immunohistochemical analysis of the case in the capillary endothelium of the sample confirmed positive for Ki-67, vimentin, CD34 marker, as well as the presence of a more abundant inflammatory infiltrate, which was not the case in our patient (20). Evans et al. described fibrous formations on the palate as highly limited, solid, independent formations, which do not infiltrate the surrounding bone (21).

\section{Rasprava}

Pojava POF-a nepoznate je etiologije i može biti povezana $s$ različitim predisponirajućim čimbenicima. U literaturi se rabe različiti nazivi za tu tvorbu kao što su fibrozni epulis ili kalcificirajući fibroblastični granulom (9). Periferni fibromi i fibromatoze u usnoj šupljini $>1 \mathrm{~cm}$ u promjeru imunohistokemijskom analizom povezani su s CD 34, alpha-smooth muscle actinom (a-SMA), vimentinom, Ki-67(Mib1) i transforming growth factor-alphom (TGF-a). TGF-a se smatra povezanim s proliferacijom fibroblasta i pojačanom fibroblastičnom aktivnošću (10). Klinički je teško utvrditi razliku između neoplazme i nekontrolirane reaktivne hiperplazije fibroznoga tkiva. Trauma i iritacija još se uvijek smatraju glavnim predisponirajućim čimbenicima za nastanak fibromatoznih tvorbi (11). Eversole i Leider u svojem istraživanju navode da se recidiv pojavljuje u 28 \% slučajeva nakon enukleacije unutarkoštanoga osificirajućeg fibroma (12). Takve tvorbe teško je diferencijalnodijagnostički razlikovati od granuloma perifernih divovskih stanica, fibroma, piogenih granuloma, kalcificirajućih epitelnih odontogenih cista, kalcificirajuće odontogene ciste i još nekoliko drugih odontogenih i neodontogenih cista (13).

U pregledu literature od 1950. godine do 2017. autori se koriste različitim nazivima za tvorbe sličnog oblika i izgleda. Hiebert i Brooks 1950. upotrebljavaju naziv fibrom turdog nepca, a histopatološkom analizom njihova uzorka ustanovljeno je da tvorba sadržava nakupine fibroblasta i maturirane stanice vezivnoga tkiva (14). Beers sličnu tvorbu naziva bilateralnim fibromom nepca s gotovo identičnim nalazom PHD analize (15). Od 2010. do 2017. godine Di Lorenzo i suradnici i Palaia promjene nazivaju simetricna fibrozna hiperplazija nepca, odnosno idiopatska simetrična hiperplazija nepca $(16,17)$. Godine 2017. Syed i suradnici promjenu na nepcu nazivaju simetričnom nepčanom fibromatozom. Histološka analiza tvorbe opisuje avaskularno fibrozno tkivo $s$ tankom kolagenom mrežom i vrlo slabom mitoznom aktivnošću i minimalnom nakupinom upalnog infiltrata (18). 


\section{Conclusion}

Bilateral symmetrical palate hyperplasia is a very rare formation. We presented a case report of a 47-year-old woman with the mentioned change. The surface of the formation was smooth, without any ulcerations. Also, it was solid and extended bilaterally from the canine area to the border of the soft palate.

Treatment included an excision of the formation from healthy tissue and removal of the affected periosteum and periodontal ligament. It is necessary to remove all irritating factors, as well as factors that can cause tissue trauma.

\section{Conflict of interest}

The authors report no conflict of interest.

Authors' contributions: T.K. has determined the clinical diagnosis of the presented case, and he has developed the main idea of the paper. He performed the surgery. He actively participated in the process of writing and processing of the work, as well as in the collection of references. A.B. has participated in establishing a clinical diagnosis, and assisted in surgical removal of hyperplasia. She actively wrote the paper, collected references, and participated in text writing and photo processing. I. F. As a full university professor, she mentored the preparation of the paper, participated in the clinical diagnosis, and the preparation of the paper. T. K. As a university professor, he coordinated the preparation of the paper, participated in the clinical diagnosis, and in the writing and editing of the paper.

\section{Zaključak}

Bilateralna simetrična hiperplazija nepca vrlo je rijetka tvorba. Opisan je slučaj žene u dobi od 47 godina s bilateralnom simetričnom hiperplazijom čija je površina bila glatka, bez ulceracija i solidna, te se protezala obostrano od područja očnjaka do granice s mekim nepcem.

Terapija navedene tvorbe uključuje eksciziju tvorbe do zdravoga tkiva, s uklanjanjem zahvaćenog periosta i PDL-a. Potrebno je ukloniti sve iritirajuće čimbenike te one koji mogu prouzročiti traumu tkiva.

\section{Sukob interesa}

Autori ne navode sukob interesa.

Doprinos autora: T. K. - kao prvi autor koji je utvrdio kliničku dijagnozu prikazanog slučaja, bio je začetnik rada, operirao je pacijenta. Aktivno je sudjelovao u pisanju i obradi rada, kao i u prikupljanju literature; A. B. - sudjelovala je u postavljanju kliničke dijagnoze i pomagala u kirurškom uklanjanju hiperplazije, aktivno je pisala rad, prikupljala reference i sudjelovala u obradi teksta i fotografija; I. F. - kao redovita sveučilišna profesorica mentorirala je pripremu rada, sudjelovala u kliničkoj dijagnozi i pripremi rada; T. K. - kao sveučilišni profesor koordinirao je pripremu rada, sudjelovao u kliničkoj dijagnozi te u pisanju i uređivanju rada.

\section{Sažetak}

Bilateralna simetrična fibrozna hiperplazija nepca nije često opisana u literaturi. Uzrok te patološke promjene nije u cijelosti poznat. Razvoj hiperplazije može također biti povezan s genetskom mutacijom mekoga tkiva gingive ili njezinom ozljedom. Opisujemo slučaj 47-godišnjeg pacijenta koji je razvio formaciju koja se obostrano očitovala u tvrdom nepcu. Nakon izrezivanja u tkivu nije bilo histoloških elemenata koji bi upućivali na agresivno ponašanje tvorbe. Klinička i histološka dijagnoza formacije t vrlo je rijetka obostrana simetrična hiperplazija nepca.
Zaprimljen: 4. prosinca 2020.

Prihvaćen: 20. travnja 2021.

Adresa za dopisivanje

dr. sc. Tomislav Katanec, dr. dent. med

Klinika za stomatologiju KBC-a u

Zagrebu,

Odjel oralne kirurgije

telefon: +385989482617

tkatanec@sfzg.hr

MeSH pojmovi: nepce; hiperplazija

Ključne riječi: xxx

$\mathrm{xxx}$

\section{References}

1. Raymond J Fonseca. Oral and maxillofacial surgery. London: Elsevier Health Science; 2000. p. 122-123.

2. Jaimes M, Muñante J, Olate S, Rodriguez-Chessa Jg, De Albergaria-Barbosa Jr, Mazzonetto R, et al. Inflammatory fibrous hyperplasia treated with a modified vestibuloplasty: a case report. J Contemp Dent Pract. 2008 Mar 1;9(3):135-41.

3. Mesquita Ra, Okuda E, Jorge Wa, De Araújo Vc. Collagenous fibroma (desmoplastic fibroblastoma) of the palate: a case report. Oral Surg Oral Med Oral Pathol Oral Radiol Endod. 2001; 91(1):80-84.

4. Isaac U, Issac Js, Ahmed Khoso N. Histopathologic features of oral submucous fibrosis: a study of 35 biopsy specimens. Oral Surg Oral Med Oral Pathol Oral Radiol Endod. 2008;106(4):556-60.

5. Pedron Ig, Carnava Tg, Utumi Er, Moreira La, Jorge Wa. Hiperplasia fibrosa causada por protese: remoção cirúrgica com laser Nd:YAP”. Rev Clín Pesq Odontol. 2007;3(1):51-56.

6. John RR, Kandasamy S, Achuthan N. Unusually large-sized peripheral ossifying fibroma. Ann Maxillofac Surg. Jul-Dec 2016;6(2):300-303.

7. Trasad VA, Devarsa GM, Subba Reddy VV, Shashikiran ND. Peripheral ossifying fibroma in the maxillary arch. J Indian Soc Pedod Prev Dent. Jul-Sep 2011;29(3):255-9.
8. Kumar SK, Ram S, Jorgensen MG, Shuler CF, Sedghizadeh PP. Multicentric peripheral ossifying fibroma. J Oral Sci. 2006;48(4):23943.

9. Lee KW. The fibrous epulis and related lesions. Periodontics. 1968;6(6):277-92.

10. Rotaru H, Choi JY, Hong SP, Lee YC, Yun KL, Kim SG. Trans forming growth factor-a and oral fibroma: immunohistochemical and in situ hybridization study. J Oral Maxillofac Surg. 2003 Dec;61(12):1449-54.

11. Neville BR, Damm DD, Allen, CM, Bouquot JE, editors. Oral \& maxillofacial pathology, 2nd end. Philadelphia; WB Saunders: 2002. p. 438-439.

12. Eversole LR, Leider AS, Nelson K. Ossifying fibroma: A clinicopathologic study of sixty-four cases. Oral Surg Oral Med Oral Pathol. 1985;60(5):505-11.

13. Cuisia ZE, Brannon RB. Peripheral ossifying fibroma-a clinical evaluation of 134 pediatric cases. Pediatr Dent. May-Jun 2001;23(3):245-8.

14. Hiebert, AE, Brooks, HW. Fibroma of the palate. Plast Reconstr Surg. 1950;5(6):532-535.

15. Beers MD . Bilateral fibroma of the palate: report of case. J Oral Surg (Chic). 1953 Oct;11(4):330-2. 
16. Di Lorenzo S, Milia A, Corradino B, Cordova A. Uncommon case of symmetrical fibrous hyperplasia of the hard palate. Eur Rev Med Pharmacol Sci. 2010;14(2):145-146.

17. Palaia G. Idiopathic fibrous hyperplasia of the palate. Ann Stomatol (Roma). 2013 Oct 24;4(Suppl 2):35. eCollection 2013.

18. Syed A, Clark AN, Bouquot JE. Symmetrical palatal fibromatosis. Tex Dent J. 2017;1330:650-651,680-685.

19. Vasconcelos AC, Gomes AP, Tarquinio S, Abduch-Rodrigues E, Mesquita R, Silva K. Oral Bilateral Collagenous Fibroma: A pre- viously unreported case and literature review. J Clin Exp Dent. 2018; 10(1):96-99.

20. Mesquita RA, Okuda E, Jorge WA, de Araújo VC. Collagenous fibroma (desmoplastic fibroblastoma) of the palate: a case report. Oral Surg Oral Med Oral Pathol Oral Radiol Endod. 2001 Jan;91(1):80-4.

21. Evans HL. Desmoplastic fibroblastoma. A report of seven cases. Am J Surg Pathol. 1995 Sep;19(9):1077-81. 